\title{
Black Mesa Flora Study
}

\author{
James K. McPherson, Ph.D. \\ Department of Botany \\ Oklahoma State University \\ 22 February 1993
}

\section{Summary of season's work}

The following constitutes a report on field, laboratory, and library work done in 1992 on the flora of the State Parks-The Nature Conservancy preserve property at Black Mesa. This property is north of the town of Kenton; R1E, T6N, sections 28-33 (portions), and R1E, T5N, S6 (portion), Cimarron County, Oklahoma.

I spent 14 full days collecting plants on the preserve, each time camping at the state park a few miles away the nights before and after, so very little travel time was used on collecting days. Collecting dates in the 1992 growing season were 2-3 March, 6-7 April, 30 April-1 May, 14-16 May, 26 June, 2-3 September, and 21-22 September. During each trip an effort was made to visit and collect in as many different types of sites as possible.

\section{Collections of 199 species were}

made. These were handled in the conventional way, with duplicate specimens being made. One set is deposited in the Oklahoma State University Herbarium, and the other in the Bebb herbarium at the University of Oklahoma.

\section{Interpretation of findings}

Flora. The families Compositae, Leguminosae, and Gramineae are represented by the largest numbers of species. However, 47 other families are present. Members of the Gramineae (grass) family clearly dominate most of the landscape. The Pinaceae (in the inclusive sense) is the other dominant family, due to the numerous members of the genus Juniperus in some areas.

Two species that are endemic were collected. The shrub Glossopetalon planitierum (=Forsellesia p.), Celastraceae, which is known only from a few adjacent counties in the Texas panhandle, one nearby county in New Mexico and the Black Mesa area of Cimarron County, OK. The type locality is "near the top of Black Mesa, Cimarron Co." It is possible that the type locality is now on the preserve, though it probably is not possible to know with certainty. The other endemic collected was the perennial herb Astragalus puniceus, Leguminosae. It is known only from the Mesa de Maya area (Las Animas County, Colorado; Union County, New Mexico; and Cimarron County, Oklahoma) and Deaf Smith County, Texas. Both species are fairly common locally, but can be considered rare in a general sense.

Four other species are worth mentioning in this context. I did not collect them, but know about them from the literature (Rogers, 1953; Harrington 1964; Waterfall 1969; McGregor et al. 1977; McGregor et al. 1986, Correll and Johnston 1970). Sarcostemma lobata, Asclepiadaceae, is apparently known only from Black Mesa. It is likely that this species will be found on the preserve, and 
seems to be a legitimate rare species. Lesquerella calcicola, Cruciferae, Palafoxia macrolepis, Compositae, and Swertia coloradensis, Gentianaceae, are all endemic in southeastern Colorado, but are at higher elevations and/or on soil types that are not found in Oklahoma, so probably are not on the preserve.

Finally, Pericome glandulosa, Compositae, was collected and is described by Rogers (1953) as being an endemic, but has been reduced to varietal status by Harrington. Thus it is now Pericome caudata var. glandulosa. The reduction appears legitimate. The type locality for it is also Black Mesa. In my opinion, var. glandulosa is only a local variant of a widespread species. It occurs on sandstone hills which are common in the region and there does not seem to be any substantial distinct feature about it. Concern about it is probably not justified. I collected 199 species. Rogers' (1953) list contains 578 species and 11 varieties, a total of 589 taxa. There are some caveats to be mentioned about the comparison of numbers, however. First, Rogers collected from a much larger area. Second, he included types of sites that are not on the preserve (elevations up to 6850 $\mathrm{ft}$., Cimarron River bed and floodplain, sand dunes, and a salt-pan). Finally, some of his species seem questionable in view of present knowledge.

The following is a list of species I collected that Rogers (1953) did not. Identifications will be rechecked.

\section{Selaginellaceae Selaginella underwoodii ${ }^{[1]}$ \\ Polypodiacae Cheilanthes lanosa Asplenium serpentrionale $e^{[1]}$ \\ Gramineae Bromus unioloides Eragrostis trichodes var. trichodes ${ }^{[1]}$ Cyperaceae}

Scirpus validus (S. lacustris in

Waterfall 1969)

\section{Lemnaceae}

Lemna minor

\section{Liliaceae}

Allium canadense var. fraseri

\section{Salicaceae}

Salix interior forma wheeleri

S. nigra (possibly Rogers' "Salix species")

Moraceae

$$
\text { Morus alba }{ }^{[1]}
$$

Chenopodiaceae

Suckleya suckleyana

Ranunculaceae

Clematis hirsutissima var. scottii ${ }^{[1]}$

\section{Cruciferae}

Arabis fendleri

\section{Saxifragaceae}

Ribes odoratum ${ }^{[1]}$

\section{Leguminosae}

Petalostemon tenuifolium

\section{Linaceae}

Linum rigidum var. rigidum

\section{Vitaceae}

Parthenocissus quinquefolia (ident. should be checked)

Vitis vulpina

\section{Onagraceae}

Oenothera triloba

\section{Asclepiadaceae} Asclepias arenaria ${ }^{[1]}$

Sarcostemma crispum ${ }^{[1]}$

\section{Boraginaceae}

Cryptantha minima

\section{Labiatae}

Salvia azurea var. grandiflora

\section{Rubiaceae}

Galium texense

\section{Compositae}

Ambrosia linearis $^{[1]}$ (tentative)

Aster fendleri

A. leucelene

Hymenoxys acaulis

Kuhnia chlorolepis

Solidago mollis 
Most of these species are permanent resident, "climax" types. They probably would not have immigrated into the area since Rogers made his collections in the late 1940's. The most likely explanation is that Rogers simply missed seeing them.

Vegetation. This is not a formal study of the vegetation or plant communities of the preserve, but I made observations on these attributes of the site on which I can report. Two vegetation types, in the conventional sense of Barbour and Billings, 1988, are present on the preserve. These are Juniper-Pinyon Woodland, which is on the steeper slopes of the mesa and rock outcrops, and Shortgrass Prairie, on level to gently sloping sites with deeper soil.

Within this general picture are some smaller-scale patterns. The most obvious is the presence of Cooper's Arroyo, a stream with rare-intermittent flow. It does have a pool that contains water most of the time, and its bed provides conditions that support typical moist-soil plant species such as Salix spp., Tamarix gallica, and Carex gravida. This can be termed a riparian community.

Two variants of shortgrass prairie are present. On the Berthoud loam and portions of the Travessilla stony loam (USDA, 1960) in the low-lying parts of the preserve is a prairie with many weeds, especially Erioneuron pilosum, Bothriochloa sacchariodes, and Ambrosia psilostachya. There is also a substantial amount of the cactus Opuntia imbricata which here is associated with disturbance. This portion of the preserve was the most accessible to cattle when the land was ranched, and was where most of the water was provided. It appears that overgrazing is the main cause of the abundance of weedy species and partial loss of the dominants, Buchloe dactyloides and Bouteloua gracilis.

On the Apache stony clay loam (USDA, 1960), which is found only on the basalt rock forming the top of the mesa, is a slightly different version of shortgrass prairie. The dominant grasses, Buchloe dactyloides and Bouteloua gracilis, are the same, but they are more dominant and there are fewer weeds. More of the native forbs such as Castilleja sessiliflora, Oenothera lavendulaeflora, and several Compositae are present. In my judgment, the difference is caused by a history of less disturbance, and by the soil's higher clay content. The contrast between the two variants of short grass prairie will probably diminish with time and the cessation of grazing, but differences due to the contrasting soils are likely to remain. The mesa-top community probably will have a higher diversity of climax species.

On the sides of the mesa the soils are mapped as Rough stony land and the higher parts of the Travessilla stony loam (USDA, 1960). This is where the JuniperPinyon woodland is found. Juniperus monosperma is the strong dominant here, with only a few Pinus edulis trees, despite the traditional name of the vegetation type. There are differing communities within this area, but they are not as clearly separated as is the case with the prairie communities. The most noteworthy group of species here, after $J$. monosperma, is the shrubs. On the drier, open slopes are Rhus aromatica, Cercocarpus montanus, Brickellia brachyphylla, and $B$. californica. Also, Opuntia imbricata is here, appearing less weedy than it does in the prairies. In one area near the east end of the preserve the endemic Glossopetalon planitierrum is a component of the shrub flora. All are fairly widely spaced so that walking among them is easy. 
In the canyons where more moisture accumulates and there is some shelter from the wind is a denser shrub community. Near the bottoms of the deeper canyons it is dense indeed, becoming impenetrable in places. Most of the species just listed are present, and they are joined by Prunus americana, $P$. virginiana, Rubus deliciosus, Ptelea trifoliata, and Celtis reticulata. Here also is Juniperus scopulorum, a Rocky Mountain species, which is quite uncommon and is very close to the extreme edge of its range.

Throughout the Juniper-Pinyon vegetation is an array of grasses, mostly of different species from the prairie. Very common are Poa fendleriana and Eragrostis cilianensis. In pockets of deep soil, often only a meter or two across, are Andropogon gerardii, Sorghastrum nutans, and Schizachyrium scoparium. These are dominants of the tallgrass prairie 150 and more miles east, but grow well here in small, favorable sites. The Juniper-Pinyon woodlands are the least disturbed communities on the preserve. The only other local community that should be noted is the very weedy one that develops in and around the usuallydry, man-made "tanks" or stock-watering ponds. These ponds contain water so seldom that its main effect is to drown any climax species that invade the bed. The original construction work left a massive scar, and trampling by cattle has perpetuated the disturbance. Species commonly found in and around the ponds include Proboscidea louisianica,
Xanthium strumarium, Cenchrus

pauciflorus, and Suckleya suckleyana. If left alone, without cattle trampling, the dams and margins of these ponds will slowly revert to shortgrass prairie. The beds will be weedy as long as the dams occasionally retain water.

\section{References Cited}

Barbour, M.C. and W.D. Billings (eds.). 1988. North American terrestrial vegetation. Cambridge, MA: Cambridge Univ. Press.

Correll, D.S. and M.C. Johnston. 1970. Manual of the vascular plants of Texas. Renner, TX: Texas Research Foundation.

Harrington, H.D. 1964. Manual of the plants of Colorado. Athens, $\mathrm{OH}$ : Sage Books/Swallow Press.

McGregor, R.L. et al. 1977. Atlas of the flora of the Great Plains. Ames, IA: Iowa State University Press.

McGregor, R.L. et al. 1986. Flora of the Great Plains. Lawrence, KS: University Press of Kansas.

Rogers, C.M. 1953. The vegetation of the Mesa de Maya Region of Colorado, New Mexico, and Oklahoma. Lloydia:257-290.

United States Department of Agriculture. Soil Conservation Service; Soil survey: Cimarron County, Oklahoma. U.S. Government Printing Office. 1960.

Waterfall, U.T. 1969. Keys to the flora of Oklahoma. $4^{\text {th }}$ ed. Stillwater, OK:

[Published by the author] 


\title{
BLACK MESA FLORA STUDY
}

\author{
Year Two Supplement
}

James K. McPherson

20 January 1994

\section{INTRODUCTION}

This is a supplement to my report on the same subject of last year. It is assumed that the present readers have that report and can refer to it. This paper is organized the same way and is in the same sequence as last year's.

\section{SUMMARY OF 1993 WORK}

I spent seven full days collecting, using the same plans \& format as in 1992. The dates were; 25-26 April, 9-10 May, 31 May, and 6-7 October.

Collections of 30 species new for this project were made, bringing the total to date to 229 . They were handled and distributed as before.

\section{INTERPRETATION OF FINDINGS}

The count of families has risen to 53 from 50, because of collection of single members of the Selaginellaceae, Sapindaceae, and Polemoniaceae.

Two species should be mentioned. (1) The Parthenocissus at the Mesa may be $P$. vitacea, the "western" species. It is known from a few places in the state, but on most herbarium specimens it cannot be distinguished from $P$. quinquefolia so it is hard to know how common it is. Waterfall did not realize $P$. vitacea was in Okla. (or did not accept it), so most people have assumed that it was all $P$. quinquefolia. It will be next season before I will know which we have at the Mesa. (2) There is an Ambrosia there that keys to A. linearis, which is "Apparently restricted to a few localities in the open high plains of eastern Colorado; rarely collected." There are no specimens in OU's or our herbaria, so Ron Tyrl and I sent it off to University of Colorado for identification. We haven't heard back from them yet. It looks very much like $A$. psilostachya, which is abundant that area; this may be why it is overlooked.

My 1993 estimate of 250-260 species being present on the Preserve still seems reasonable. Since 229 have been collected, about 20-30 remain to be found. 


\section{Editors' Notes:}

This paper is published with the courteous agreement of The Nature Conservancy for whom it was prepared. The approximate GPS location of Black Mesa State Park is between latitudes 36.833 and 36.861 and longitudes 102.862 and 102.900. The elevation of the mesa ranges from $4960 \mathrm{ft}(1512 \mathrm{~m})$ to $4973 \mathrm{ft}$ $(1516 \mathrm{~m})$. It is now contained within Black Mesa State Park which contains approximately 349 acres of land.

The original species list has been updated as follows:

[1] On July 1, 1994, ten days before his death, Jim McPherson generated plant labels for 15 additional specimens he had collected on June 7 at Black Mesa on his way to California. With the generous assistance of Iris McPherson, his wife, they are included in the flora and the taxa summary table below.

$\begin{array}{ll}\text { Families } & 55 \\ \text { Genera } & 172 \\ \text { Species } & 244 \\ \text { Infraspecific taxa } & 41 \\ \text { Exotic species } & 16\end{array}$

Folley's "Additions to Black Mesa Flora Study", which follows McPherson's flora in this volume, includes areas of Black Mesa State Park not included in his study and lists only species that are not included here.

[2] The International Code of Botanical Nomenclature "conserved" several traditional family names when they standardized the family nomenclature. McPherson used some of these traditional names in the Black Mesa report, but since they are falling into disuse standardized names are provided here. Current species' names have also been provided. Name changes are updates only. No specimens were reexamined for this publication.

Kartesz, J.R. (1994). A synonymized checklist of the vascular flora of the United States, Canada, and Greenland. Portland, OR: Timber Press.

Voss, E. G., H.M. Burdet, W.G. Chaloner, V. Demoulin, P. Hiepko, J. McNeill, R.D. Meikle, D.H. Nicolson, R.C. Rollins, P.C. Silva, \& W. Greuter, 1983. International code of botanical nomenclature, adopted by the Thirteenth International Botanical Congress, Sydney, August 1981).

[3] Introduced species are indicated in this list.

Correll \& Johnston. 1970. Manual of the vascular plants of Texas. Renner, TX: Texas Research Foundation.

Taylor, R.J. \& C.E.S. Taylor. 1991. An annotated list of the ferns, fern allies, gymnosperms and flowering plants of Oklahoma. [Published by the authors at Southeastern Oklahoma State University].

Tyrl, R.J., Susan Barber, Paul Buck, Wayne Elisens, James Estes, Patricia Folley, Lawrence Magrath, Constance Taylor, and Rahmona Thompson. The flora of Oklahoma. The Flora of Oklahoma Editorial Board.

Forthcoming.

USDA-NRCS 2003. The PLANTS database. (http://plants.usda.gov/plants.) 


\section{SPECIES BY FAMILY OF THE BLACK MESA RESERVE, CIMARRON COUNTY} James K. McPherson, 1992

\section{$(93)=$ species added in $1993(94)=$ species added in $\left.1994^{[1]}\right)$}

\section{Division/Class/Family}

Selaginellaceae

Selaginella underwoodii (93)

\section{Polypodiaceae}

Cheilanthes eatoni

Cheilanthes feei (93)

Cheilanthes lanosa

Notholena standleyi

Pellaea atropurpurea

var. purpurea (93)

Woodsia oregan (94)

Asplenium septentrionale (94)

\section{Pinaceae}

Juniperus monosperma

Juniperus scopulorum

Pinus edulis

Gramineae

Agropyron smithii var. smithii

Andropogon gerardii

Aristida longiseta

Aristida purpurea

Aristida wrightii

Bothriochloa saccharoides

Bouteloua curtipendula

Bouteloua eriopoda

Bouteloua gracilis

Bouteloua hirsuta var. hirsutea

Bromus anomalus var. lanatipes

Bromus tectorum

Bromus unioloides

Buchloe dactyloides

Cenchrus carolinianus

Chloris verticillata

Echinochloa cruzgalli

Elymus virginicus var. jejunus

Elymus canadensis (94)

Eragrostis cilianensis

\author{
Common Family Name \\ Standardized Name ${ }^{\text {[2] }}$
}

spikemoss family

spikemoss

$$
\begin{aligned}
& \text { true fern family } \\
& \text { Eaton's lip fern } \\
& \text { slender lip fern } \\
& \text { hairy lip fern } \\
& \text { star cloak-fern } \\
& \text { cliff-brake }
\end{aligned}
$$

\section{Oregon woodsia \\ forked spleenwort \\ Dryopteridaceae \\ Aspleniaceae}

\section{pine family}

one-seed juniper

Rocky Mtn. Juniper

pinyon pine

\section{grass family}

western wheatgrass ${ }^{[3]}$

big bluestem

Fendler three-awn

purple three-awn

Wright three-awn

silver bluestem

side-oats grama

black grama

blue grama

hairy grama

nodding brome

cheat $^{[3]}$

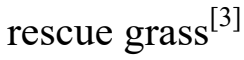

buffalo grass

sandbur

windmill grass

barnyard grass ${ }^{[3]}$

Virginia wildrye

Canadian wild rye

stinkgrass $^{[3]}$

\section{Poaceae}


Eragrostis trichodes var.

var. trichodes (94)

Erioneuron pilosum

Hilaria jamesii

Hordeum pusillum

Lycurus phleoides Muhlenbergia

torreyi Oryzopsis hymenoides

Oryzopsis micrantha

Panicum capillare var. capillare

Panicum hallii (93)

Panicum obtusum

Poa fendleriana Schedonnardus

paniculatus Schizachyrium

scoparium Setaria leucopila

Sitanion hystrix

Sorghastrum nutans Sporobolus

cryptandrus

Stipa comata

Stipa scribneri

Vulpia octoflora

\section{Cyperaceae}

Carex gravida

Cyperus schweinitzii (93)

Scirpus americanus var.

polphyllus

Scirpus validus

\section{Commelinaceae}

Commelina erecta

var. angustifolia (94)

Tradescantia occidentalis

\section{Lemnaceae}

Lemna minor

\section{Liliaceae}

Allium canadense var. fraseri

Yucca glauca

\section{Salicaceae}

Populus deltoids

Salix amygdaloides

Salix interior forma wheeleri

Salix nigra sand love grass

fluffgrass $^{[3]}$

galleta

little barley

wolftail

ring muhly

Indian ricegrass

little-seed ricegrass

common witchgrass

Hall panic grass

vine-mesquite

muttongrass

tumblegrass

little bluestem

plains bristlegrass

squirreltail

Indian grass

sand dropseed

thread-and-needle

Scribner needlegrass

six-weeks fescue

\section{sedge family}

sedge

umbrella sedge

bulrush

bulrush

\section{spiderwort family}

erect dayflower

western spiderwort

\section{duckweed family}

duckweed

\section{lily family}

wild onion

plains yucca

\section{willow family}

cottonwood

peach-leaf willow

sandbar willow

black willow
Scirpus tabernaemontanus

Elymus elymoides
Salix exigua 


\begin{tabular}{|c|c|c|}
\hline $\begin{array}{l}\text { Ulmaceae } \\
\text { Celtis reticulate }\end{array}$ & $\begin{array}{l}\text { elm family } \\
\text { hackberry }\end{array}$ & \\
\hline $\begin{array}{l}\text { Santalaceae } \\
\text { Commandra pallida }\end{array}$ & $\begin{array}{l}\text { sandalwood family } \\
\text { bastard toad-flax }\end{array}$ & $\begin{array}{c}\text { Commandra umbellata } \\
\text { ssp. pallida }\end{array}$ \\
\hline Urticaceae & nettle family & \\
\hline Parietaria pennsylvanica & Pennsylvania pellitory & \\
\hline $\begin{array}{l}\text { Polygonaceae } \\
\text { Eriogonum jamesii } \\
\text { Eriogonum lachnogynum } \\
\text { Polygonum lapathifolium } \\
\text { Polygonum ramosissimum } \\
\text { Rumex crispus }\end{array}$ & $\begin{array}{l}\text { buckwheat family } \\
\text { James wild buckwheat } \\
\text { wild buckwheat } \\
\text { pale smartweed } \\
\text { knotweed } \\
\text { curly dock }\end{array}$ & \\
\hline $\begin{array}{l}\text { Chenopodiaceae } \\
\text { Ceratoides lanata } \\
\text { Chenopodium album (93) } \\
\text { Chenopodium incanum (93) } \\
\text { Kochia scoparia }\end{array}$ & $\begin{array}{l}\text { goosefoot family } \\
\text { winterfat } \\
\text { lamb's quarters } \\
\text { goosefoot } \\
\text { kochia }\end{array}$ & \\
\hline $\begin{array}{l}\text { Salsola kali var. tenuifolia } \\
\text { Suckleyla suckleana }\end{array}$ & $\begin{array}{l}\text { Russian thistle } \\
\text { poison suckleya }\end{array}$ & Salsola kali var. tragus \\
\hline $\begin{array}{l}\text { Amaranthaceae } \\
\text { Amaranthus retroflexus }\end{array}$ & $\begin{array}{l}\text { pigweed family } \\
\text { rough pigweed }{ }^{[3]}\end{array}$ & \\
\hline $\begin{array}{l}\text { Nyctaginaccae } \\
\text { Mirabilis carletonii (93) } \\
\text { Mirabilis linearis var. subhispida }\end{array}$ & $\begin{array}{l}\text { four-o'clock family } \\
\text { Carleton's four-o'clock } \\
\text { narrowleaf four-o'clock }\end{array}$ & \\
\hline Portulacaceae & purslane family & \\
\hline Portulaca retusa & purslane & $\begin{array}{l}\text { Portulaca oleracea } \\
\text { ssp. oleracea }\end{array}$ \\
\hline Ranunculanceae & buttercup family & \\
\hline $\begin{array}{l}\text { Clematis hirsutissima var. scottii }(93) \\
\text { Delphinium virescens var. penardi }\end{array}$ & $\begin{array}{l}\text { virgin's bower } \\
\text { prairie larkspur }\end{array}$ & $\begin{array}{c}\text { Delphinium carolinianum } \\
\text { var. virscens }(93)\end{array}$ \\
\hline Ranunculus sceleratus & cursed crowfoot & \\
\hline $\begin{array}{l}\text { Fumariaceae } \\
\text { Corydalis aurea }\end{array}$ & $\begin{array}{l}\text { fumitory family } \\
\text { golden corydalis }\end{array}$ & \\
\hline $\begin{array}{l}\text { Capparidaceae } \\
\text { Polanisia dodecandra }\end{array}$ & $\begin{array}{l}\text { caper family } \\
\text { clammy-weed }\end{array}$ & \\
\hline
\end{tabular}


Volume 3, Number 1, December 2003

\section{Cruciferae}

Arabis fendleri

Descurania pinnata var. intermedia

Erysimum capitatum

Lepidium densiflorum

Lesquerella ovalifolia

Saxifragaceae

Ribes cereum

Ribes odoratum

Rosaceae

Cercocarpus montanus var. argenteus

Physocarpus monogynus (93)

Prunus americana var. americana

Prunus virginiana

Rubus deliciosus

Leguminosae

Amorpha canescens

forma canescens (94)

Astragalus crassicarpus

var. paysoni (93)

Astragalus gracilis

Astragalus lotiflorus

Astragalus missouriensis

Astragalus mollissimus

Astragalus puniceus

Dalea aurea

Dalea candida

var. oligophylla

Dalea enneandra

Dalea formosa (93)

Dalea jamesii

Glycyrrhiza lepidota (93)

Hoffmannseggia drepanocarpa (93)

Hoffmannseggia jamesii

Krameria lanceolata

Melilotus officinalis

Mimosa borealis

Petalostemum tenuifolia

Psoralea argophylla (93)

Psoralea tenuiflorum

Vicia americana mustard family

rock cress

tansy mustard

wallflower

peppergrass $^{[3]}$

bladderpod

saxifrage family

western red currant

buffalo currant

rose family

mountain mahogany

mountain ninebark

wild plum

choke cherry

boulder raspberry

pea family

lead plant

ground-plum

slender milk-vetch

lotus milk-vetch

Missouri milk-vetch

wooly locoweed

Trinidad milk-vetch

golden prairie-clover

white prairie-clover

nine-anther prairie-clover

feather plume

James dalea

wild licorice ${ }^{[3]}$

sicklepod rush-pea

James rush-pea

ratany

yellow sweet clover $^{[3]}$

pink mimosa

slimleaf prairie-clover

silver-leaf scurf pea

scurf pea

American vetch

\section{Brassicaceae}

Grossulariaceae

Ribes aureum

var. villosum (93)
Fabaceae

Caesalpinia drepanocarpa

Caesalpinia jamesii

Krameriaceae

Dalea tenuifolia

Pediomelum argophylla

Psoralidium tenuiflorum 


\section{Linaceae}

Linum lewisii

Linum rigidum var. rigidum

Zygophyllaceae

Tribulus terrestris

Rutaceae

Ptelea trifoliata

Polygalaceae

Polygala alba

\section{Euphorbiaceae}

Argythamnia humilis

Argythamnia mercurialina

Croton texensis

Euphorbia fendleri

Euphorbia lata

Euphorbia dentata forma cuphosperma

Euphorbia marginata

Tragia ramosa

\section{Anacardiaceae}

Rhus aromatica var. pilosissima

Toxicodendron radicans

Celastraceae

Glossopetalon planitierum

Sapindaceae

Sapindus drummondii (93)

\section{Vitaceae}

Parthenocissus quinquefolia

Vitis vulpina

\section{Malvaceae}

Sphaeralcea angustifolia

Sphaeralcea coccinea

\section{Tamaricaceae}

Tamarix gallica

\section{Violaceae}

Hybanthus verticillatus flax family

blue flax

stiff flax

\section{caltrop family}

goat head $^{[3]}$

\section{citrus family}

wafer-ash

\section{milkwort family \\ milkwort}

\section{spurge family}

wild mercury

wild mercury

Texas croton

Fendler spurge

hoary spurge

toothed spurge

snow-on-the-mountain

noseburn

\section{sumac family}

lemon sumac

poison ivy

\section{staff-tree family}

grease-bush

\section{soap-berry family}

soap-berry

\section{grape family}

Virginia creeper

fox grape

Chamaesyce fendleri

Chamaesyce lata

\section{Crossosomataceae}

Sapindus saponaria

var. drummondii

mallow family

globe mallow

scarlet globe mallow

\section{tamarisk family}

salt cedar $^{[3]}$

violet family

green violet

McPherson, J.K. 
Volume 3, Number 1, December 2003

\section{Loasaceae}

Mentzelia decapetala

Cactaceae

Echinocereus viridiflorus

Mammillaria vivipara (93)

Opuntia imbricata

Opuntia phaeacantha var. major

Opuntia trichophora (93)

\section{Onagraceae}

Gaura coccinea var. coccinea

Oenothera serrulata

Oenothera albicaulis (93)

Oenothera lavendulaefolia

Oenothera triloba

\section{Umbelliferae}

Cymopteris acaulis (93)

Cymopteris montanus

\section{Asclepiadaceae}

Asclepias arenaria (94)

Asclepias asperula

var. decumbens

Asclepias macrotis (94)

Asclepias pumila

Asclepias uncialis (93)

Sarcostemma crispum (94)

\section{Convolvulaceae}

Convolvulus incanus

Evolvulus nuttallianus

Ipomoea leptophylla (94)

\section{Polemoniaceae}

Gilia laxiflora (93)

\section{Boraginaceae}

Cryptantha jamesii

Cryptantha minima

Cryptantha thyrsiflora stick-leaf family

blazing star

\section{cactus family}

green-flowered hedgehog

pincushion cactus

Escobaria vivipara

var. vivipara

cholla

prickly pear

prickly pear Opuntia polyacantha

var. trichophora

evening primrose family scarlet butterfly flower

evening primrose

Calyophus serrulatus

evening primrose

evening primrose

stemless evening primrose

parsley family

(no common name)

(no common name)

Calyophus lavandulifolius

milkweed family

sand milkweed

low milkweed

longhood milkweed

threadleaf milkweed

dwarf milkweed

\section{Apiaceae}

\section{morning glory family}

field bindweed ${ }^{[3]} \quad$ Convolvulus arvensis

Nuttall evolvulus

bush morning-glory

phlox family

gilia

Ipomopis laxiflora

\section{borage family}

popcorn flower

small popcorn flower

popcorn flower
Cryptantha cineria

var. jamesii 
Lappula redowskii stickseed var. occidentalis

Lithospermum incisum

Onosmodium molle var. occidentale

Verbenaceae

Verbena canadensis

Verbena bracteata

Labiatae

Monarda pectinata

Salvia azurea var. grandiflora

\section{Solanaceae}

Chamaesaracha conioides

Physalis virginiana

var. sonorae (94)

Physalis lobata

Solanum elaeagnifolium

Solanum rostratum (93)

\section{Scrophulariaceae}

Castilleja sessiliflora

Penstemon albidus

Penstemon ambiguous (94)

Veronica anagallis-aquatica

Martyniaceae

Proboscidea louisianica

Plantaginaceae

Plantago purshii var. purshii

Plantago purshii var. spinulosa (93)

\section{Rubiaceae}

Galium texense

Cucurbitacaeae

Cucurbita foetidissima

Compositae

Agoseris cuspidate

Ambrosia sp. (93)

Ambrosia psilostachya

Artemisia filifolia

Artemisia glauca cutleaf puccoon

false gromwell

vervain family

rose vervain

prostrate vervain

mint family

spotted beebalm

pitcher sage

nightshade family

false nightshade

Virginia ground cherry

ground cherry

silverleaf nightshade

buffalo bur

\section{figwort family}

downy indianpaintbrush

white beardtongue

water speedwell ${ }^{[3]}$

\section{unicorn-plant family}

devil's claw

\section{plantain family}

wooly plantain

wooly plantain

madder family

Texas bedstraw

cucumber family

buffalo gourd

sunflower family

false dandelion

ragweed

western ragweed

sandsage

silky wormwood
Lappula occidentalis

var. occidentalis

Glandularia canadensis

Lamiaceae

Quincula lobata
Asteraceae

Nothocalais cuspidata

Artemisia dracunculus

McPherson, J.K. 
Oklahoma Native Plant Record

Volume 3, Number 1, December 2003

Artemisia ludoviciana

Aster ericoides

Aster fendleri

Aster leucelene

Aster oblongifolius

Berlandiera lyrata

Brickellia brachyphylla

Brickellia californica

Chrysopsis villosa var. villosa

Chrysothamnus nauseosus

Cirsium undulatum

Conyza canadensis var. canadensis

Dyssodia papposa

Engelmannia pinnatifida

Erigeron divergens var. cinereus

Evax prolifera

Gaillardia pinnatifida

Grindelia squarrosa var. nuda

Gutierrezia sarothrae

Haplopappus spinulosus

Helianthus annuus

Hymenopappus flavescens

Hymenopappus tenuifolius

Hymenoxys acaulis

Hymenoxys scaposa var. linearis

Kuhnia chlorolepis

Liatris punctata var. punctata

Lygodesmia juncea (94)

Lygodesmia pauciflora

Machaeranthera tanacetifolia (93)

Melampodium leucanthemum

Pericome caudate

Ratibida columnifera

Ratibida tagetes (94)

Senecio douglasii var. longilobus

Senecio plattensis

Senecio tridenticulatus

Solidago mollis

Solidago petiolaris (93)

Thelesperma megapotamicum

Townsendia exscapa
Louisiana sagewort

heather aster

Fendler's aster

white aster

aromatic aster

green eyes

(no common name)

(no common name)

golden aster

rabbit brush

wavy-leaf thistle

horseweed

fetid marigold

Engelmann's daisy

fleabane

rabbit-tobacco

blanket flower

curly-top gumweed

snakeweed

cutleaf ironplant

annual sunflower

yellow plainsman

white plainsman

stemless bitterweed

bitterweed

false boneset

dotted gayfeather

skeleton plant

skeletonweed

tansy aster

black-foot daisy

(no common name)

Mexican hat

prairie coneflower

shrub groundsel

prairie ragwort

ragwort

soft goldenrod

downy goldenrod

greenthread

Easter daisy ssp. glauca

Chaetoppa ericoides

Heterotheca villosa

var. villosa

Erigeron colomexicanus

Machaeranthera pinnatifida

Tetraneuris acaulis

Tetraneuris scaposa

Brickellia eupatorioides

var. chlorolepis

Stephanomeria pauciflora

Senecio flaccidus 
Tragopogon major (93)

Verbesina encelioides

Xanthium strumarium

Zinnia grandiflora

Moraceae

Morus alba (94) goatbeard $^{[3]}$

golden crownbeard cocklebur wild zinnia

white mulberry ${ }^{[3]}$
Tragopogon dubius

McPherson, J.K. 